\title{
Problems in Language Teaching in Elementary School
}

\author{
Elfia Sukma, Ritawati, Rahmatina, and Ari Suriani \\ Primary School Teacher Education Department \\ Universitas Negeri Padang \\ elfiasukma105@gmail.com
}

\begin{abstract}
This study aimed to determine the problems faced by teachers in the learning of writing languages on aspects of cognitive, affective, and psychomotor in primary school. This research used qualitative approach. Data were obtained based on the results of the questionnaire answered by the teacher. Data were analyzed by using qualitative data analysis approach. The subjects consisted of 303 teachers of grade 4.5, and 6 elementary schools. The results show that teachers face problems in language learning. Problems experienced by teachers on the cognitive aspect is the lack of understanding of teachers to the nature of reading and writing, the lack of understanding of teachers in teaching writing languages. On the affective aspect the lack of motivation of teachers in the written language. As for the psychomotor aspect is the learning process of reading and writing has not been implemented optimally, and the assessment process has not been done optimally. As a result students are less able to understand the text reading and students are less able to express ideas or ideas in writing.
\end{abstract}

Keywords-- problem; language teaching; elementary school

\section{INTRODUCTION}

Learning to read and write is suspected to be less successful. In fact, studies show that literacy among Indonesian children is still far behind other children in other countries. The fact is that the purpose of learning to read and write in school is very difficult to be realized in the field. This, according to Waluyo (in Suara Merdeka, 19 October 2002) is due to Indonesian language learning is still often given theoretically which resulted in less students' language performance. Linguistic and literary theories are mostly preached to the teacher in front of the class. In fact, the model of learning evaluation is also theoretical.

Suwandi also stated that most of Indonesian language learning has not been able to realize students who are proficient in Indonesian language. According to him, there are several reasons that cause it to happen, among them are: (1) teaching and learning activities have not fully emphasized the ability of language, but more on the mastery of the material, and (2) some teachers argue that the success of students is often seen from the value achieved.

During this writing is still done traditionally by emphasizing the results of student tutorials, not on the process that should be done. The students immediately write without learning how to write. Teachers usually have provided some kind of title or topic of essay and ask students to choose one of them. The students are then asked to directly practice writing. After completion, the results are collected, corrected and assessed by the teacher. This kind of learning model is constantly happening which causes students to feel bored and unhappy with writing learning. Finally writing learning activities is considered something very burdensome burden. As a result, it is natural that the writing skills of the students are very low. This resulted in the students having no writing experience. This situation occurs since students sit in elementary school until high school, even impossible happened also in college.

Meanwhile, reading learning is still done traditionally. According to Roe, Stoodt, and Burns (1995) there are some false assumptions about reading reading at school. The assumptions are as follows. First, reading learning is only focused on primary school. Some people assume that students who have graduated from elementary school have mastered reading skills. In fact, the mastery of reading skills requires a long process and should be reading activities are part of a continuous life. Second, separate reading learning with learning in various fields of study. Properly, learning and reading activities are part of all the subjects in school. In each lesson, reading is the main activity. Third, the language teacher is the person most responsible for the success of reading learning in school. The responsibility of reading learning can not only be charged to language teachers. All teachers of study (IPS, science, mathematics, arts, sports, and others) should participate in reading activities in their respective field of study. Reading skills are supposed to be a means to master various fields of science so it is natural that all teachers of the field of study participate in the responsible.

The usual steps taken regularly in reading learning are students reading (tinny or in the liver), teachers explaining difficult words, students answering questions, and reciting the content of the reading. This activity proved to cause students to feel bored with reading lessons. Therefore, it is natural that students' reading skills are inadequate.

In this regard, it is necessary to innovate a more appropriate reading and writing learning model. Especially with the enactment of Competency Based Curriculum which clearly requires that in learning more emphasized on the development of language ketermpilan, including reading and writing. 
According to Tomkins and Hoskisson (1995) reading is a transactive process when readers negotiate meaning or interpretation. Weaver as quoted by Tomkins and Hoskisson (1995) states that during reading the meaning does not come naturally from text to reader, but in reading there is a complex negotiation between the text and the reader determined by the context of the immediate situation and the broad sociolinguistic context. The context of the immediate situation includes the language community in which the reader resides and becomes the user of the language and the reader's expectation of a reading activity based on his previous experience.

Reading skills can be seen as a process and as a result (Burns, et al., 1984). As a process, reading includes: (a) visual processes, (b) thought processes, (c) psychomotor processes, (d) metacognitive processes, and (e) technological processes (Crawley and Montain, 1995). As a visual process, in the reading occurs eye movements. The reader's eye makes fixations and jumps from one fixation to another in fast motion (saccadic movement). As a process of thinking, reading includes word recognition, literal understanding, and criticism. Word recognition includes the ability to read words quickly and precisely without the aid of a dictionary. A literal understanding includes the skills to understand words and understand the grouping of words into phrases, clauses, sentences, and paragraphs. In this literal understanding, the reader also tries to understand the author's intent so that the reader can make a conclusion and respond to the reading. In giving criticism, the reader creates original ideas.

As a process of psycholinguistics, in reading interaction occurs between the mind and language. During this process, the schemata really helps the reader in making sense. The reader's knowledge of phonology, semantics, syntax greatly helps the reader in understanding and interpreting messages. Meanwhile, as a metacognitive process, reading activities include planning, strategy determination, monitoring, and assessment. In reading, the reader identifies the tasks in reading, determines strategies for reading comprehension, monitors comprehension, and judges success.

As a technological process, reading activities can include reader interaction with a computer. By using a specific program, the computer can say the words to the reader and can read the entire reading with various kinds and sound characteristics. Seen as a result, in reading there is the attainment of mind communication and the reader's feelings with the author (Burns, et al., 1984). This communication occurs because there is a common knowledge and assumption between the reader and the author. This communication is highly dependent on the reader's understanding of all reading processes.

There is a wide range of reading skills. In primary schools, for example, reading learning is divided into two stages: (1) reading the beginning given to students in grades I and II, and (2) further reading given to third, fourth and fourth graders (Supriyadi et al. 1992). In the initial reading phase, the emphasis of reading learning is on reading techniques (Zuchdi and Budiasih, 1996/1997). In the advanced reading stage, the learning pressure is in reading comprehension. Thus, in reading learning in grades IV and V SD, more emphasized learning comprehension reading. At the level of junior and senior high school education, it is advisable that reading comprehension learning should be emphasized in an effort to help students master various concepts in various fields of study.

Meanwhile, writing skills are the most complex language skills. Writing is related to three other language skills.

Writing skills require constant practice. Therefore, the development of these skills should be approached with a process approach. Learning writing with this process approach is based primarily on the results of research on how a writer actually manages to compose his tutorial. Therefore, writing learning that emphasizes the product in the form of tutulis should be changed.

\section{METHOD}

To answer the question of the problems faced by teachers in learning writing language, this study used qualitative descriptive analysis techniques. Those problems were about the competencies of the cognitive, affective, and psychomotor aspects experienced by teachers and students in teaching writing in primary school. Data collection was done by using questionnaire. Respondents answered about the description form. The question consists of three items: (1) What are the problems faced by the teacher in the linguistic material on the cognitive aspect ? (2) What are the problems faced by the teacher in the linguistic material on the affective aspect? (3) What problems faced by teachers in linguistic material on psychomotor aspects?

Questionnaires involved 303 respondents, 4th, 5th, and 6th grade teachers in Kota Padang. To facilitate the data collection, 303 respondents were given initials R1, R2, R3, R4, R5, and so on until R303.

Models reserved by Miles \& Huberman (1992) in qualitative data analysis are data reduction, data presentation, and conclusions (Agusta, 2003; Emzir, 2010; Miles \& Huberman, 1992). Data reduction was the process of selecting, focusing attention, facilitating, abstracting and transforming data obtained in memorandum of study location. It involves: formulating data, encoding, tracking themes and composing, for example by way of selection, summary, and paraphrase. Presentation of data is to compile informations that may provide the possibility of making conclusions and implementing actions. The presentation of qualitative data was in the form of narrative text. The collected data was analyzed using a qualitative approach to develop certain themes or codes. 


\section{FINDING AND DISCUSSION}

The following is described the results of the analysis of the data obtained based on the results of interviews with 303 respondents. From the cognitive domain, the problems experienced by teachers are the lack of understanding of teachers to the nature of reading and writing, the lack of understanding of teachers in teaching reading and writing. In the affective aspect the lack of motivation of teachers in reading and writing. As for the psychomotor aspect is the learning process of reading and writing has not been implemented optimally, and the assessment process has not been done optimally.

\section{Lack of Master's Understanding of the Nature of Reading}

The nature of reading refers to the understanding, purpose, and benefits of reading. Studies can show that teachers are less able to teach language skills because teachers understand the notion of reading skills as expressed by R65 respondents.Respondents R200 stated that teachers still lack understanding of reading skill because some elementary school teachers have non graduate background from PGSD department. This affects the learning of reading.

Furthermore, the problem experienced by teachers in reading skills is in understanding the purpose and benefits in learning reading skills as expressed by respondents $\mathrm{R} 52$.

\section{Lack of Master's Understanding of the Nature of Writing}

The essence of writing refers to the understanding, purpose, and benefits of reading. Studies show that teachers are less able to teach language skills because teachers understand the notion of writing skills as expressed by the R65 respondent.

Respondent R200 stated that teachers still do not understand the essence of writing skill because some elementary school teachers have non graduate background from PGSD department. This affects the learning of writing.Furthermore, the problem experienced by teachers in writing skills is in understanding the purpose and benefits in learning writing skills as expressed by respondents R52.

\section{Lack of Master's Understanding of Linguistic Learning}

In presenting learning material of writing language which need to be mastered is model of learning. The goal is that the learning objectives can be achieved optimally. The difficulties experienced by most teachers are not yet understanding the appropriate learning model that can be used in learning the language of writing, choosing the appropriate learning with the level of student development and the steps of using the learning model. As expressed by respondents R54 that teachers who lack the mastery of learning will result in students being not interested in the learning provided by the teacher.

Based on statements expressed by respondents R54 revealed that if the teacher is difficult to determine the appropriate learning, consequently the learning is not interesting for students and students difficult to understand the material presented by the teacher. Thus the less than optimal subject objectives are achieved optimally as expressed by respondents $\mathrm{R} 75$.

\section{Lack of Teacher Motivation in Reading}

Motivation needs to be possessed by a teacher. With the motivation, a teacher can create various learning experiences for students. Studies can show that teachers' motivation in reading less. This is in accordance with that revealed by respondents R269 that the lack of motivation to students in the subjects of language.

If a teacher has a lack of motivation in teaching reading learning, of course this will result in students also less motivated in learning.

\section{Lack of Teacher Motivation in Writing}

Motivation needs to be possessed by a teacher. With the motivation, a teacher can create various learning experiences for students. Studies can show that teachers' motivation in writing less. This is in accordance with that revealed by respondents R269 that the lack of motivation to students in the subjects of language.

If a teacher has a lack of motivation in teaching writing lessons, this will certainly lead to students also less motivated in learning.

\section{Reading Learning has not been implemented optimally}

Studies can show that teachers are having problems teaching reading skills. The problem is the ability of teachers to teach reading skills, the use of media in learning, the use of learning methods, subjects are still besifat cognitive, and the selection of learning materials. The ability of teachers in teaching reading skills is how teachers present reading subjects so that learning is meaningful for students. As stated by respondent R219.

Indonesian language subjects, especially reading skills in elementary schools can not be separated from the ability of teachers in designing learning, such as the selection of materials and learning models. As revealed by respondents 
R289 that teachers are less able to choose materials and learning models in accordance with the development and ability of students so that the effect on students' reading ability.

In addition, the problem experienced by teachers is the use of media in learning. As stated by respondents R30 that the use of appropriate learning media can support the implementation of learning including reading skills.

\section{Learning Writing has not been implemented optimally}

Studies can show that teachers have problems teaching their writing skills. The problem is the ability of teachers to teach writing skills, the use of media in learning, the use of learning methods, subjects are still besifat cognitive, and the selection of learning materials. The ability of teachers in teaching writing skills is how teachers present writing subjects so that learning is meaningful for students. As stated by respondent R219.

Indonesian language subjects, especially writing skills in elementary schools can not be separated from the ability of teachers in designing learning, such as the selection of materials and learning models. As revealed by respondents R289 that teachers are less able to choose materials and learning models in accordance with the development and ability of students so that the effect on students' reading ability.

In addition, the problem experienced by teachers is the use of media in learning. As stated by respondents R30 that the use of appropriate learning media can support the implementation of learning including writing skills.

\section{The assessment process has not been done optimally}

The purpose of the assessment is to measure skills in different contexts. Based on the results of the study found that some teachers still experience difficulty in assessing the learning activities of written language, as expressed by respondents R41.Assessment needs to be done by the teacher. Assessment is done to see student progress in learning writing language. For that teachers need to know the aspects that need to be assessed in the subjects of writing language such as assessing the ability meyimak and tell stories as expressed by R92.

Understand the language assessment procedure Write (R12/ Gr)Furthermore, the difficulties experienced by teachers are in understanding the assessment procedure. The point is when the judgment is done as in the beginning, the process, and the end. As expressed by respondents R12 that teachers difficulties in understanding the procedures of writing language assessment. Though writing language assessment procedures needed to measure the success of learning.

The assessment by questionnaire indicates that the subject matter of the written language in Indonesian subjects in elementary school is a difficult material for teachers to teach it, as well as for students to understand it. This assessment can be done according to Balfas (2008) which states that the literary subjects so far still feel difficult and scary for students. Teachers are still using traditional subject models so students are just as listeners. Further discussion of the results of this study provides an explanation to three parts which consists of (1) problems of cognitive aspects, (2) problems of affective aspects, and (3) problems of psychomotor aspects.

\section{Problems of the Cognitive Aspects}

Based on the questionnaire of the questionnaire analysis, most teachers still have problems in understanding the written language. Teachers' knowledge of written languages is lacking. Teachers do not know what it is written language, the purpose of learning it, and its benefits. According to A. Chaedar Alwasilah (1994), teachers' knowledge of written language is lacking; literature is taught by unprofessional teachers, teachers do not know to teach written language well (Wei, 1999). Based on the questionnaire was also found that some teachers have backgrounds instead of graduates from the department of PGSD. It affects the ability of students in reading and writing.

Furthermore, Kurniawan (1997), expressed that most teachers are less able to teach the written language. This problem has resulted in a way of teaching teachers. The pattern of teaching done so far is that students are assigned to read the book and then do the exercises. Though the role of teachers is in need in creating a model of learning. Therefore a teacher must know the essence of written language, the skills of reading and writing. The results of the study of the learning model is that teachers do not understand the appropriate learning model used in writing language subjects. Whereas in the learning process teachers need to use the model. The use of appropriate models can streamline teachers to achieve subject objectives. Sutikno (2009) states, "The method of subjects is a way of presenting the lesson material done by educators to occur the process of subjects in students in an effort to achieve goals.

The use of teaching media in the teaching of literature is also important for teachers. Learning will become more meaningful for using the media, students are expected not only to listen to teachers, but also to experience and interact directly with the media. The use of media can bridge the gap between the world inside and outside the classroom (Kemp, 1985). Furthermore, according to Brown (1987) that the learning media used in subjects activities can affect the effectiveness of learning. 


\section{Problems of the Affective Aspects}

Overall, teachers experience problems from the affective aspect in the subjects of literary appreciation of children. These problems include a lack of teacher motivation in reading and writing.

The problem of the affective aspect is the courage of students to write both in the seat and in front of the class. Most students find it difficult to express ideas, shame, and lack confidence. Most people will be skilled at writing if they have written publicly. Therefore to skillfully write necessary exercise.

In the learning skills of writing many alternatives that can be used such as the use of image media. Other ways can also be used, such as giving a scheme. The intended scheme is that the points to be discussed are coveted or mapped, as explained in the principle of using concept mapping in reading learning. Another way that teachers can use is to use a strategy called "see and say" (Bailey and Savage, 1994, p. 124-125).

\section{Problems of Psychomotor Aspects}

Studies may indicate that teachers have problems with language learning. Most teachers have problems in speaking literature. The problem is the process of learning to read and write has not been implemented optimally, and the assessment process has not been done optimally.

Assessment in the learning process is done by the teacher as an integral part of the learning itself. That is, assessment can not be separated from penyususnan and implementation of learning. The assessment process includes the collection of evidence showing achievement of student learning. According to Griffin and Nix (1991) assessment is a statement based on a number of facts to explain the characteristics of someone or something. In addition, according to Sunarti (2014), assessment is interpreted as an activity of interpreting the measurement data or activities to obtain information.

\section{CONCLUSION AND RECOMMENDATION}

Writing language subjects are generally a difficult subject for teachers in school. The difficulties are not only experienced by teachers, but also by students. The difficulty is expressed in three aspects: cognitive, affective, and psychomotor.

Problems experienced by teachers on the cognitive aspect is the lack of understanding of teachers to the nature of reading and writing, lack of understanding of teachers in teaching writing languages. On the affective aspect the lack of teacher motivation in written language. As for the psychomotor aspect is the process of learning to read and write has not been implemented optimally, and the assessment process has not been done optimally. As a result students are less able to understand the text reading and students are less able to express ideas or ideas in writing.

\section{References}

Bellenger, L. (1996). L'Expression orale: une approche nouvelle de la parole expressive. Paris: ESF Editeur.

Bermawi, M. (2009). Desain pembelajaran. Yogyakarta: Insan Madani.

Boyatziz, R. E. (2008). Competencies in the 21 st century. Journal of Management Development. Vol. 27 (1), pp. 5-12.

Cahyani, I., \& Iyos, A. R. (2006). Pendidikan bahasa indonesia. Bandung: UPI Press.

Cahyani, I. (2005). "Pengembangan Model Pembelajaran Menulis Bermuatan Kecakapan Hidup untuk Meningkatkan Kebermaknaan Pembelajaran Bahasa Indonesia”. Laporan Penelitian Tidak Diterbitkan. Bandung: Lemlit UPI (Lembaga Penelitian Universitas Pendidikan Indonesia).

Coxhead, A., \& Byrd, P. (2007). Preparing Writing Teachers to Teach the Vocabulary and Grammar of Academic Proses. Journal of Second Language Writing, 16 (3), September 2007, p. 129-147.

Depdikbud. 1985. Membaca dan pengajarannya. Jakarta : Universitas Terbuka.

Dixon, C.N. \& Nessel, D. (1983). Languange experience approach to reading and writing: languange-experience reading for second language learners. Englewood Cliffs: Prentice Hall.

Farris, J.P. (1993). Language arts: A process approach. Madison: Brown \& Bencmark Publishers.

Freyhofer, H. (2008). "I Hate History Papers" dalam Journal on Writing Across the Curriculum, 11. Michigan, USA: University of Michigan

Hadley, A.O. (2001). Teaching language in context. Boston: Heinle \& Heinle Publishers.

Haryadi dan Zamzani. (1997). Peningkatan keterampilan berbahasa indonesia. Depdikbud dirjen Dikti bagian Proyek Pengembangan Pendidikan Guru Sekolah Dasar.

Hayon, Y. (2003). Membaca dan menulis wacana. Jakarta: Storia Grafika.

Kellog, RT. (2008). Training writing skills: A cognitive developmental perspective journal of writing research. USA: Department of Psychology, Saint Louis University

Kravetz. (2004). Human resource management. McGraw-Hill, Boston.

McAshan \& Hildreth, H. (1979). Competency based education and behavioral objective. NJ: Englewood Cliffs.

Purwo, BK. (1990). Pragmatik dan pengajaran bahasa. Yogyakarta: Kanisius.

Saddhono, K. (2012). Meningkatkan keterampilan berbahasa indonesia (teori dan aplikasi). Bandung: Karya Putra Darwati. 
Suadnyani, N. (2009). Penerapan Strategi POWERS untuk Meningkatkan Keterampilan Menulis Argumentasi Mahasiswa Kelas X.A SMA Negeri 1 Kubutambahan. Thesis (unpublished). Singaraja: Universitas Pendidikan Ganesha.

Suwandi, S. (2008). Serbalinguistik: Mengupas perlbagai praktik bahasa. Surakarta: LPP UNS dan UNS Press.

Webster, G. \& Baylis, F. (2003). "Moral residue." In S. B. Rubin \& L. Zoloth (Eds.), Margin of error: The ethics of mistakes in the practice of medicine. (pp. 217-232). Hagerstown, MD: University Publishing Group. 